Acta medico-historica Rigensia (2019) XII: 09-21

doi:10.25143/amhr.2019.XII.01

Aistis Žalnora

\title{
Principles of Physical Education of Children in the Works of Jędrzej Śniadecki
}

\section{Abstract}

The article is devoted to the concept of physical education of children that were presented in papers of Jędrzej Śniadecki (1768-1838), a famous Polish-Lithuanian doctor, anthropologist, biologist, chemist, and philosopher. The study revealed that the works of J. Śniadecki were partly characteristic of the Enlightenment period. The main goal of Śniadecki's papers was to educate society in order to fight with superstitions and negative habits that were widely spread in the working class as well as the upper class. He focused on preventive measures that would help to maintain good physical and mental health of a child, family and society. Śniadecki's attitude included some Romanticist features. He believed that the modern way of living was dangerous for human health because of numerous social factors that changed the primary perfection, purity and natural powers of the human body. As an opposition to the modern lifestyle he puts naturalistic way of living.

However, Śniadecki was also one of the first anthropologists in Lithuania and Poland. His works were the first attempts to find correlations between numerous factors such as nutrition, heredity and development of the human body. Moreover, Śniadecki could be referred to as one of the pioneers in didactics. His insights related to the different teaching methods applied to the pupils' age and sex remain relevant until now.

Keywords: J. Śniadecki, Vilnius, physical education, children, anthropology. 


\section{Biographical Details in Short}

Jędrzej Śniadecki (1768-1838) was one of the first Polish-Lithuanian anthropologists. The year 2018 marked his $250^{\text {th }}$ anniversary. Jędrzej Michał Jan Śniadecki was born on 30 November, 1768 as a son of Jędrzej Śniadecki and Franciszka from Giszczyńskich. ${ }^{1}$ His mother Franciszka came from a noble Leliwa family. ${ }^{2}$

Jędrzej gained his secondary education at the Gymnasium in Trzemeszno. Soon with the help of his elder brother prof. Jan Śniadecki (1956-1830) he continued his education in Cracow Nowodworski Gymnasium, which he graduated in July 1787 receiving the golden medal "Diligentiae" from the hands of the last king of Lithuanian-Polish Commonwealth Stanisław August Poniatowski (1732-1798). ${ }^{3}$

In the period from $1787 / 1788$ to $1790 / 1791$, J. Śniadecki studied mathematics and physics, and later medicine at the Main School of the Crown (The University of Cracow). ${ }^{4}$ Shortly thereafter he went to Pavia where in the autumn of 1791 he began studies in practical medicine, chemistry and physiology as well as doctors' practice in Milan. ${ }^{5}$ In 1793, he went to London, later, in 1793-1795, he studied at the University of Edinburg. In 1795, he took practice in hospitals of Vienna. In 1796-1797, he served as a family doctor in Volhynia (now Ukraine). ${ }^{6}$

Śniadecki was a professor of chemistry and medicine at the Main School of the Grand Duchy of Lithuania (transformed into the Imperial Vilnius University in 1803) and the Medico-Surgical Academy in Vilnius. He was the president of Vilnius Medical Society as well as an editor of Dziennik Wileński, the daily newspaper of Vilnius. ${ }^{7}$

Śniadecki was a scientist with many talents. In 1800, he published the first textbook of chemistry in Poczatki chemii in the Polish language in Vilnius. ${ }^{8}$ In 1804-1811, he published one of his most famous works Teoria

1 Birutė Railienè, Andrius Sniadeckis (Vilnius, 2005), 30.

2 Bibliografia Literatury Polskiej-Nowy Korbut (Warszawa, 1970), t. 6, No. 1: 300-308.

3 Bolesław Skarżyński, Jędrzej Śniadecki: Wybór pism naukowych I publycznych (Kraków, 1952), 10.

4 Ibid., 11.

5 Adam Wrzosek, Jędrzej Śniadecki: życiorys I rozbiór pism (Kraków, 1910), 24.

6 Birutè Railienè, Andrius Sniadeckis, 23.

7 Ibid., 86-88, 92.

8 Tomas Venclova, "Sniadeckis Andrius" in Vilniaus Vardai (Vilnius: R. Paknio leidykla, 2006), 136. 
jestestw organycznych (Theory of organic beings), ${ }^{9}$ which was later translated in French, German, Russian, and other languages. That was one of the first textbooks for biology and biochemistry in the World. Śniadecki was also a supporter of French philosophy rationalist school as well as evolutionist. He believed that every species of flora and fauna developed in a certain order because of external factors. ${ }^{10}$

Jędrzej Śniadecki was married to Konstancja Mikułowska from Wolhynia. He was a father of two daughters and a son. ${ }^{11}$ This also influenced his personal aspirations for research in education. He died at the age of 69 in Vilnius on May 11, 1838. He was buried in a rural cemetery in Horodniki, in the county of Vilnius (now territory of Belarus), located near the family estate of Śniadeckich in Bołtup. ${ }^{12}$

\section{The Problem of Physical Education of Children}

One of the fields of scientific interest of J. Śniadecki was hygiene and physical education. His first paper related to the above-mentioned topic of physical education of children was published already in 1805. The article named Uwagi o fizycznym wychowaniu dzieci (Notes on the physical education of children) ${ }^{13}$ later evolved until growing into a book $O$ fizyczne wychowaniu dzieci (On the physical education of children) ${ }^{14}$ in 1840 . Another version of the book Fizycznie wychowanie dzieci (Physical education of children) was printed in 1855, in Sonok. ${ }^{15}$ The book was reprinted several times, the latest in 1920, and it was published in Warsaw. ${ }^{16}$ Recently the book was translated in the Belarusian language. ${ }^{17}$ The current study

9 Jędrzej Śniadecki, Theory of Organic Beings, red. Birutè Railienè and Rimvydas Baranauskas (Vilnius: Vilniaus universiteto leidykla, 2018).

10 Tomas Venclova, "Sniadeckis Andrius", 136.

11 Bolesław Skarżyński and Jędrzej Śniadecki, Wybór pism naukowych I publycznych (Kraków, 1952), 18, 27.

12 Adam Wrzosek, Jędrzej Śniadecki: życiorys I rozbiór pism (Kraków, 1910), 54-55.

13 Jędrzej Śniadecki, "Uwagi o fizycznem wychowaniu dzieci," Dziennik Wileński, No. 5 (1805): 1-52; No. 7 (1805): 226-247.

14 Jędrzej Śniadecki, O fizycznem wychowaniu dzieci (Warszawa, 1840).

15 Fizycznie wyhowanie dzieci dzieło Jędrzeja Śniadeckiego, red. Kazimierz Józef Turowski (Sonok, 1855).

16 Jędrzej Śniadecki, Ofizycznem wychowaniu dzieci, red. Alfred Tom (Warszawa, 1920).

17 Andriaus Sniadeckio 250-ųju gimimo metinių minejjimas Baltarusijoje, http://www. mab.1t/lt/naujienos/2325?fbclid=IwAR1iF_PEUrapFXEcMPIEQRrXoDWZMGGTZk9qyUh8Zld9adJbWxvYx8jH6k 
was based on primary analysis of this historical text of the book printed in 1840 in Warsaw. Some of the ideas that will be discussed could already be found in the article. ${ }^{18}$

Śniadecki's ideas expressed in the book O fizycznem wychowaniu dzieci could be divided in two basic topics. The first being hygiene and development of physical health of children. The second topic can be named naturalistic or evolutionary philosophy.

Śniadecki starts his book (as well as the article) with a short clarification of what physical education is, as well as provides relevance of his study. He states that all the efforts that help to educate a child physically should be called physical education. ${ }^{19}$

According to him, there is little scientific research done on the issue of physical education of children, and because of that this art has not become science. As a result, every family and every society, is relying on its own experience. Most often, it is considered enough to educate children in the same way as once they were educated, because that is thought to be the best way. However, since many parents and teachers, as well as governors themselves have no proper education, they cannot give proper education to children. ${ }^{20}$ Moreover, "philosophers constructed their theories based on moral issues, but not human body. Some have tried to show themselves as wise men, others as clever rulers of their states or great administrators, others have played great family leaders, namely parents, men or exemplary sons". ${ }^{21}$ However, according to Śniadecki, neither philosophy nor some separate personal experience could be used as guidelines in creating the science of physical education. He believed that history as an experience of entire generations could be that guidance. ${ }^{22}$

Śniadecki believed that science of upbringing of a child must be based on dualism between body and spirit: both the body and the soul must be educated. "In nature, these things are inseparable, though people can separate them but only for convenience, to focus on one or the other of these

18 Jędrzej Śniadecki, "Uwagi o fizycznem wychowaniu dzieci," Dziennik Wileński, No. 5 (1805): 1-52; No. 7 (1805): 226-247.

19 Jędrzej Śniadecki, O fizycznem wychowaniu dzieci (Warszawa, 1840), 9-10.

20 Jędrzej Śniadecki, “Uwagi o fizycznem wychowaniu dzieci”, Dziennik Wileński, No. 5 (1805): 1-3.

21 Jędrzej Śniadecki, O fizycznem wychowaniu dzieci (Warszawa, 1840), 5-6.

22 Ibid., 14. 
aspects". ${ }^{23}$ He claimed that physical development helps to preserve health and strength, but it is not medicine itself. Despite the fact that health depends heavily on medicine, it does not mean that caring for a child is "feeding a child with medications".

"Such attitude can only be seen as funny and silly [..]. Caring for a child means not only protecting the child from separate cases, but also hardening him and building his health as a whole. Genuine physical education means creating preconditions for a child to grow up and become stronger to the point where his life is full, and ultimately he would not become a burden to society". ${ }^{24}$

It has been accepted that one of the key accents in the concept of good physical educations is proper timing and individual approach in each case. The Professor emphasised the importance of timing as a lot of defects would be easily corrected and diseases prevented if they were noticed at the right time: "If a child was born with a weak constitution and no one took proper care of him in early years or months, he may become a prisoner of medicine until the end of his life". He claimed that every human is born with somewhat different biological characteristics, so physical education cannot be universal as it must be based on characteristics of each individual: "Nature rewarded people with unequal abundance: some people are stronger, others are weaker, but natural gifts and health can easily be lost by misuse". 25

\section{Hygiene and Physical Education of Infants and Small Children}

Because of the above-mentioned reasons, Śniadecki divided his book in seven chapters each of which was devoted to a different period of a child's life or specific question. In the first chapter, pieces of advice for good marriage are given. Chapter two is devoted to health of a pregnant woman. Chapter three is devoted to the problem of the health of infants. Chapter four deals with health of children until the age of seven. Chapter five is devoted to the health of children from the age of seven until adolescence.

23 Jędrzej Śniadecki, “Uwagi o fizycznem wychowaniu dzieci,” Dziennik Wileński, No. 5 (1805): 4.

24 Ibid., 5.

25 Jędrzej Śniadecki, O fizycznem wychowaniu dzieci (Warszawa, 1840), 22-23. 
Chapter six deals with issues of teenagers. And lastly, chapter seven gives pieces of advice of how to correct defects in children.

Some of the insights found in the book could be compared with later ideas of eugenics or pronatalism. In the first chapter, Śniadecki argues that health of a child heavily depends on health of his parents. Therefore, marriage cannot be created with for the sake of position, honour, and money since it would be irresponsible for future offspring. According to him, the only significant criterion when choosing a husband or wife is the age and health of that person. However, noble people often ignored this. Because of that many ailments, weaknesses and chronic diseases in their families were bypassed from their ancestors to their descendants, sons, grandchildren, and grandchildren in a more severe form..$^{26}$

It would be impossible to discuss every idea that was mentioned in Śniadecki's work. Therefore, the ideas that look interesting or really strange, or the ideas that could be relevant even in our times will be addressed. When discussing health and hygiene of an infant, the Professor gives some cosy facts. For example, in the $19^{\text {th }}$ century it was suggested that a baby should be washed with salted water or even wine. The Professor mocks blind mimicry of Ancient Greek texts: "It's a pity we don't have a Styx River baths anymore as many would try to dip their own children into that water in order to create a number of new Achilles". ${ }^{27}$ Śniadecki remained rational and he did not support unreasoned or even dangerous hygienic measures. He claimed that the easiest and most rational choice is just simple water. However, the water should not be cold, and the baths should not be too frequent. The water for bathing the child should be warm, but later the temperature should be gradually lowered until it would become cold. Thus, it would work as a measure that would help hardening the baby. According to the Professor, it would prevent many diseases related to cold in the future. ${ }^{28}$

Some of the facts written in the book seem to be unbelievable and need some more explanation for a modern reader. One of these facts is practice of deforming the head of infants. Śniadecki wrote that some "careful old ladies" wrapped or squeezed the head of a child to compresses the scull of

\footnotetext{
26 Jędrzej Śniadecki, "Uwagi o fizycznem wychowaniu dzieci”, Dziennik Wileński, No. 5 (1805): 11-13.

27 Jędrzej Śniadecki, O fizycznem wychowaniu dzieci (Warszawa, 1840), 46.

28 Ibid.
} 
the child in order to give the child the desired shape of the scull. ${ }^{29}$ In his book Śniadecki also explained that actions such as useless practice were probably related with aesthetics as the deformed infants head looked not normal to those old ladies. ${ }^{30}$ Nevertheless, the above-mentioned practice could also be related with a kind of backward interpretation of Gall's ideas. Francis Joseph Gall (1758-1828) was a pioneer of phrenology science. He believed that the shape of a human skull shows the intellectual and other fundamental faculties like recollection of people, mechanical ability, and talents for poetry; or it may also show hereditary criminal instincts. ${ }^{31}$ Therefore, it might be presumed that the old ladies wanted to shape the head of the child in order to give noble features for the infant [A. Ž.]. However, in this case as well as in the other similar cases the professor remained rational. He condemned such practice as harmful, since it would harm not only a child's skull, but also its mental development. ${ }^{32}$

Śniadecki also gave dietary recommendations for infants and children. He strongly supported breastfeeding. According to Śniadecki, breastfeeding is essential for infants. Thus, a father should choose a proper mother for a child: "The mother should be well built, physically strong and young (not older than 30 years old), villager instead of a delicate, old and weak lady from the city" because such woman would feed her baby properly. It is very important that the mother herself would feed her child as much as she can. At the time when she feeds the baby, she should be in good mood and calm. If she is depressed, in bad mood, angry or frustrated, she should not feed the baby until she feels better. Otherwise, those negative emotions might be passed on the infant, and that could cause illness. ${ }^{33}$ However, some of Śniadecki's recommendations on a child's nutrition remain unreasoned. He recommended that giving children too much of meat should be avoided as it has a "downward effect on life expectancy". 34

29 Jędrzej Śniadecki, "Uwagi o fizycznem wychowaniu dzieci”, Dziennik Wileński, No. 5 (1805): 18.

30 Jędrzej Śniadecki, O fizycznem wychowaniu dzieci (Warszawa, 1840), 48.

31 The Editors of Encyclopaedia Britannica, "Phrenology", https://www.britannica.com/ topic/phrenology

32 Jędrzej Śniadecki, “Uwagi o fizycznem wychowaniu dzieci," Dziennik Wileński, No. 5 (1805): 18.

33 Ibid., 19-24.

34 Jędrzej Śniadecki, O fizycznem wychowaniu dzieci (Warszawa, 1840), 124. 
Nevertheless, some of Śniadecki's pieces of advice remain topical these days. For example, the Professor recommended that an infant should be breastfed until the age of 6 months, then other food could be gradually included in a baby's ration. ${ }^{35}$ That is much identical to modern recommendations.

One of the basic ideas of his physical education concept could be referred to as naturalism. The Professor believed that everything that is natural is a source of health. Staying in fresh air in nature is natural and healthy. In contrast, all cramped houses are just like prisons that people have created for themselves. Because of that one should not expect healthy conditions in hospitals that are created for sick rather than healthy people. ${ }^{36}$

Despite the fact that Śniadecki was a medical doctor, he was very critical about hospitals and infant medical care of that time. He advised that children should be kept away from children's hospitals or shelters. He stated that infant mortality in such hospitals and shelters is very high mostly because of malnutrition and poor care: "Such houses, although they are considered to be shelters of love and benevolence that should be given for poor children, are slaughterhouses of human beings. Children's hospitals should be called a children's cemetery." ${ }^{37}$

\section{Raising a Child in Nature}

It looks like most of Śniadecki's theories were rather known at the time; however, many of their sources remain unknown, as the Professor gave almost no references to other authors. However, in some cases we can identify the authors and find some polemics with them. For example, J. J. Rousseau (1712-1778). The latter wrote a didactic book called Émile ou de l'éducation (Emil: On the education), which also contained recommendations for child's education. Śniadecki argues that if a great philosopher wanted to protect Emil from "physical and moral abandonment", he should have sent him out of the town to the village. ${ }^{38}$

Talking about other naturalistic or evolutionary insights, the work looks characteristic to the scientific thought of Enlightenment and

\footnotetext{
35 Jędrzej Śniadecki, O fizycznem wychowaniu dzieci (Warszawa, 1840), 55.

36 Jędrzej Śniadecki, “Uwagi o fizycznem wychowaniu dzieci”, Dziennik Wileński, No. 5 (1805): 27.

37 Ibid., 30-31.

38 Ibid., 29.
} 
Romanticism periods. However, it is believed that some thoughts bypassed its time. One of these was the idea of the potentially negative impact of modern technologies.

Sniadecki believed that a modern way of living changes natural habits and puts human health at risk. In the very begging of the work, J. Śniadecki claims:

"The nature that created a human didn't have a goal to create him for the society, but only for himself like a goal. However, the human decided to become social, and he accepted the social laws because of his own decision, need or necessity. In that way he partly renounced from his primary perfection and happiness. [..] I will not tell if humanity received some things, how many things we received from it [the civilization/social life], but I can't keep silent while speaking how much strength and health we lost". ${ }^{39}$

In order to save that "primary perfection and happiness", J. Śniadecki suggests that natural principles/laws should be followed. If a person does not maintain those principles, he suffers. As an opposition for civilized and suffering aristocracy, Śniadecki puts primitive people in their natural environment. Those people, despite material shortages, live a happy life. They are much stronger, faster and healthier. ${ }^{40}$

It is interesting that almost all of the chapters of the book include some "naturalistic or evolutionary pieces of advice". The first advice is "the significance of physical attractiveness". According to Śniadecki, a healthy person is attractive to the opposite sex. Because of that, primitive societies as well as clever Greeks, Spartans and others arranged wedding with the strongest and the most beautiful individuals. They based their decision on the most natural criterion, namely love. Sadly, in the later times people started to base their decision on different criteria such as material wellbeing, high social position etc., because of which society degraded. ${ }^{41}$

Śniadecki puts an accent on breastfeeding as a very natural interaction between a mother and a baby. This interaction, according to him, is common in all mammals and that is irreplaceable by any other means. The mother's milk is much better for a child than any other surrogate: "Like every animal

39 Jędrzej Śniadecki, O fizycznem wychowaniu dzieci (Warszawa, 1840), 9-10.

40 Ibid., 25-26.

41 Ibid., 25-29. 
has its own blood, so the milk is different, created for a particular species only." ${ }^{22}$ In the third chapter of the book, the same advice "Breastfeeding is good for baby and mother" can be found. Śniadecki was very critical about upper-class ladies who were rejecting breastfeeding in order to have more freedom. According to him, such "freedom" is harmful for the baby. Moreover, it is even more harmful for the mother's health as it quite often leads to diseases of breasts. ${ }^{43}$

In the same chapter, other pieces of advice could be found. "The newborn should not be heavily wrapped" because, first of all, the Professor is joking again, "restraining is not a polite way to welcome a new person coming to life" and, seriously speaking, because it is not natural. A child has to have a possibility to move its limbs. Only in this condition the baby will develop correctly and evenly. Lastly, by crying or moving his hands and legs, the baby expresses themselves. Usually mothers wrap children for their own comfort, in order to control the movements of a new-born. But it has nothing in common with a new-born's well-being. ${ }^{44}$

Talking about the later periods of childhood, similar rules could be stressed. Śniadecki was criticising the aristocracy that teaches their children to walk by using a kind of "walking textbooks", or, even worse, children are being tied with stripes so that they would not fall down to the ground. According to him, parents have to create natural conditions for a child. The more natural, the better. A child has to learn to walk and run by falling down on the ground (of course, the place should be safe enough so that children do not hurt themselves). Open spaces, grass or sand would suit best, but none of any other artificial measures are needed. In that way all muscles would develop evenly. In contrast, a child who is always being controlled not to fall down remains physically weaker and less evenly developed. ${ }^{45}$

It is interesting that Śniadecki digs much deeper. He claims that a child that is always under complete supervision of adults becomes not self-sufficient, as adults always make the choices for him. Thus, a child becomes irresponsible for his mistakes, since he never has a chance to take up his

\footnotetext{
42 Jędrzej Śniadecki, "Uwagi o fizycznem wychowaniu dzieci”, Dziennik Wileński, No. 5 (1805): 19-24.

43 Jędrzej Śniadecki, O fizycznem wychowaniu dzieci (Warszawa, 1840), 51-52.

44 Ibid., 63-64.

45 Ibid., 92-93.
} 
own decisions. In the case of mistake or failure he will always put blame on the rest, but he will not take up his own responsibilities. ${ }^{46}$

Other pieces of advice could sound even more innovative. In short, one could be described like this: "Sitting and cramming books into the head is not natural for children". According to Śniadecki, it is not reasonable to expect high results by restraining children to their school desks for long hours. Mental powers in children should be developed gradually. Children should spend much of their time by running and playing, and passively learning things by the table only at breaks. ${ }^{47}$

Small children can memorise a lot of things, and they could be taught to imitate adults, but it does not contribute to a child's education. ${ }^{48}$ Moreover, it may be much more harmful than useful. "Sitting, lack of movement, boredom and mortification strongly influence health and are ruining [child's] natural constitution forever. ${ }^{49}[.$.$] Mental work and sitting$ is a slowly acting poison for an adult and it affects the young very fast." 50 The Professor gives a much better alternative. That is to use a child's natural curiosity. He claims that teachers should use creative methods in order to make the subject interesting for a child. ${ }^{51}$

Despite the fact that the book was written almost 200 years ago, some of Śniadecki's insights are stunningly modern. He claims that education should be oriented to the age and sex of a child. He claims that it is not effective to teach boys and girls the same things. However, it has nothing in common with social norms. Boys and girls simply have different needs and learning styles. Boys prefer doing things, playing active games instead of sitting and listening. They do not want to recognise authority of a teacher as easily as girls do. Girls prefer listening and reading. They are not as active as boys, so they are better at arts, minor housework and other similar activities. In contrast, boys prefer more mathematical and engineering tasks that requite deep concentration. ${ }^{52}$

46 Jędrzej Śniadecki, O fizycznem wychowaniu dzieci (Warszawa, 1840), 94.

47 Ibid., 104-105.

48 Ibid., 135.

49 Ibid., 99.

50 Ibid., 143.

51 Ibid., 104-105.

52 Ibid., 126, 137-138. 
Probably one of the most difficult periods of a child's education is adolescence. Surprisingly enough, Śniadecki provides some wise pieces of advice for this period as well. He recommends the most intense work on growing of intelligence and scientific activities, arts and other for this period, since then the powers of mind and imagination are strong enough for such tasks. ${ }^{53}$ Nevertheless, his most important accent was a transformation of a child's personality from childish to the young grown up person. Śniadecki claims:

"If education has to be careful, ingenious, strong and flexible, so [adolescence] is that period. In this period, we should keep the most effective and clever efforts so that suddenly we do not lose the fruit of our eighteen-years' work. This age is the period when even our laws set the young person free and leave him for himself. If he needed freedom before, but we needed to take it, so now freedom is the most dangerous thing and we must give it to him." 54

\section{Conclusions}

Despite the fact that many years have passed, the principles of physical education that were described in the works of J. Śniadecki are still relevant. Probably the main reason for that is the human nature that changes very little as compared with the modern technology. However, a human as a biological and social unit is much more difficult than any of the technologies that were invented by humanity. Today when mental powers are much more heavily exposed than physical, we should not forget the dualism between human spirit and body that was emphasised by J. Śniadecki. It should not be divided. Śniadecki's concept of physical education include a lot of rather complex measures that contribute to both physical and mental development. Although the Professor himself states that there are no universal rules that would work for every child, his works may serve as guidelines in searching for principles in order to organise complex and balanced education of children.

53 Jędrzej Śniadecki, O fizycznem wychowaniu dzieci (Warszawa, 1840), 51-52.

${ }^{54}$ Ibid., 161. 


\section{Bērnu fiziskās audzināšanas principi J. Šnadecka darbos}

Rakstā aplūkots bērnu fiziskās audzināšanas koncepts, kas aprakstīts Jedržeja Šñadecka (Jędrzej Śniadecki, 1768-1838) darbos. J. Šñadeckis bija savulaik plaši zināms poḷu-lietuviešu ārsts, antropologs, biologs, ķīmiķis un filozofs.

Pētījumā atklāts, ka J. Šñadecka darbos daḷēji atspogulojās apgaismības periodam raksturīgās idejas. Š̀̄ ārsta galvenais mērķis bija izglītot sabiedrību, lai cīnītos pret māņticību un negatīvajiem ieradumiem, kas bija plaši izplatīti strādnieku šķiras un augstākās klases pārstāvju vidū. Autors koncentrējās uz preventīvajiem pasākumiem, kas palīdzētu saglabāt labu bērna, ǵimenes un sabiedrības fizisko un garīgo veselību. Šñadecka attieksmē iezīmējas arī romantisma iezīmes. Viṇš ticēja, ka modernais dzīvesveids ir bīstams cilvēka veselībai dažādu sociālo faktoru dēḷ, kas spēj izmainīt cilvēka ķermeņa pilnību, šks̄īstību un dabiskās spējas. Modernās dzīves pretstats, viņaprāt, ir naturālistisks dzīvesveids.

J. Šnadeckis bija viens no pirmajiem Lietuvas un Polijas antropologiem, savukārt viṇa darbi bija pirmais mēginājums rast kopsakarības starp dažādiem faktoriem, tostarp uzturu, iedzimtību un cilvēka ķermeņa attīstību. Turklāt Šnadecki var uzskatīt arī par vienu no pirmajiem didaktiķiem. Viṇa atziņas par dažādajām mācību metodēm konkrētam skolēnu vecumposmam un dzimumam joprojām ir aktuālas.

Atslēgvārdi: J. Šñadeckis, Viḷnna, fiziskā audzināšana, bērni, antropoloǵija.

\footnotetext{
Aistis Žalnora

Dr., Viḷnas Universitātes Sabiedrības veselības institūta Medicīnas ētikas, tiesību un vēstures centrs / Centre for Health Ethics, Law and History of the Institute of Public Health, Vilnius University
} 